\title{
PENINGKATAN KOMPETENSI BERWUDHU MELALUI MEDIA LAGU PADA SISWA KELAS I SD NEGERI REJODANI NGAGLIK SLEMAN
}

\author{
Ponimin \\ SD Negeri Rejodani \\ E-mail: ponimin112014@gmail.com
}

\begin{abstract}
The use of appropriate learning media will determine the success of learning in the classroom. Low competence of the students in the practice of worship, especially in the competence memorize the sequence of low ablution that needs special attention. Through the use of media is expected to track student competency in the practice of worship, especially her ablutions and competence to memorize the sequence can perform ablutions increase. The subjects were students of class I by the number of students 33 children consisting of 12 male students and 21 female students. The study concluded that through the medium of song in learning can improve the competence perform ablutions in Class I SD Negeri Rejodani Ngaglik Sleman in academic year 2015/2016. Percentage of mastery learning students has increased each cycle. At the time of prasiklus average learning achievement completeness 66.06 with $57.58 \%$, the first cycle an average of 71.67 with a mastery learning achievement of $75.76 \%$, and the second cycle average of 82.12 with the learning achievement completeness $87,88 \%$. An increase in the activity of students and teachers in the learning activities of PAI. Activities of students in the first cycle by $60 \%$. In the second cycle increased to $88.33 \%$. While the first cycle of teacher activity by $70 \%$. In the second cycle increased to $95 \%$
\end{abstract}

Keywords: media songs, competence perform ablution

\begin{abstract}
ABSTRAK
Penggunaan media pembelajaran yang tepat ikut menentukan keberhasilan pembelajaran di kelas. Rendahnya kompetensi siswa dalam praktek beribadah terutama pada kompetensi menghafal urut-urutan berwudhu yang rendah perlu mendapat perhatian khusus. Melalui penggunaan media lagu diharapkankompetensi siswa dalam praktek beribadah khususnya berwudhu serta kompetensi menghafal urut-urutan berwudhu dapat meningkat. Subjek penelitian ini adalah siswa kelas I dengan jumlah siswa 33 anak yang terdiri dari 12 siswa laki-laki dan 21 siswa perempuan.Hasil penelitian menyimpulkanbahwamelalui media lagu dalam pembelajaran dapat meningkatkan kompetensi berwudhu pada siswa kelas I SD Negeri Rejodani Ngaglik SlemanTahun Pelajaran 2015/2016. Persentase ketuntasan belajar siswa mengalami peningkatan tiap siklusnya. Pada saat prasiklus rata-rata prestasi belajar 66,06 dengan ketuntasan 57,58\%, siklus I rata-rata prestasi belajar 71,67 dengan ketuntasan $75,76 \%$, dan siklus II rata-rata prestasi belajar 82,12 dengan ketuntasan 87,88\%. Adanya peningkatan aktivitas siswa dan aktivitas guru dalam pembelajaran PAI. Aktivitas siswa pada siklus I sebesar $60 \%$. Pada siklus II meningkat menjadi $88,33 \%$. Sedangkan aktivitas guru siklus I sebesar 70\%. Pada siklus IImeningkat menjadi 95\%.
\end{abstract}

Kata kunci : media lagu, kompetensi berwudhu 


\section{A. Pendahuluan}

Salah satu tujuan pembelajaran Pendidikan Agama Islam adalah membentuk karakter siswa yang beriman dan berakhlaq yang mampu mengamalkan nilai-nilai Islami dalam kehidupan sehari-hari. Tujuan jangka panjangnya adalah membentuk karakter siswa yang mampu meneladani ajaran Islam dan mengamalkan di lingkungan masing-masing. Proses pembelajaran di sekolah harapannya mampu ditransformasikan dalam kehidupan masing-masing siswa, karena dalam perkembangannya kita dihadapkan pada suatu masa dimana kita dan siswa berhadapan langsung dengan perubahan prilaku siswa dalam mengamalkan ajaran agama Islam.

Pendidikan Agama Islam diberikan dengan mengikuti tuntunan bahwa agama diajarkan kepada manusia dengan visi untuk mewujudkan manusia yang bertakwa kepada Allah SWT dan berakhlak mulia, serta bertujuan untuk menghasilkan manusia yang jujur, adil, berbudi pekerti, etis, saling menghargai, disiplin, harmonis dan produktif, baik personal maupun sosial. Tuntutan visi ini mendorong dikembangkannya standar kompetensi dengan ciri-ciri: lebih menitik beratkan pencapaian kompetensi secata utuh selain penguasaan materi; mengakomodasikan keragaman kebutuhan dan sumber daya pendidikan yang tersedia; serta memberikan kebebasan yang lebih luas kepada pendidik di lapangan untuk mengembangkan strategi dan program pembelajaran seauai dengan kebutuhan dan ketersediaan sumber daya pendidikan.

Pemilihan dan penggunaan media pembelajaran yang tepat ikut menentukan keberhasilan pembelajaran berwudhu di kelas I SD. Apabila guru kurang maksimal dalam memilih dan menggunakan metode /strategi pembelajaran maka mengakibatkan siswa kurang berminat mengikuti proses pembelajaran pendidikan Agama Islam, rendahnya kompetensi siswa dalam praktek beribadah serta kompetensi menghafal urut-urutan berwudhu rendah.

Demikian juga yang terjadi di SD Negeri Rejodani Sleman Yogyakarta bahwa minat belajar Pendidikan Agama Islam kurang, kompetensi siswa dalam praktek beribadah khususnya berwudhu kurang dan kompetensi menghafal uruturutan berwudhu rendah. Sebenarnya guru dalam melaksanakan proses pembelajarannya sudah mencoba dan menggunakan beberapa metode dan strategi mengajar serta menggunakan media peraga gambar yang ada dalam buku pegangan siswa serta memberi 
contoh langsung, namun siswa tetap tidak bisa menghafal dan mempraktekkan urut urutan berwudhu secara benar.

Untuk itu perlu kiranya dicari media lain agar kompetensi berwudhu bagi siswa kelas I SD benar benar bisa meningkat. Solusi media pembelajaran yang lain itu adalah media lagu. Berdasarkan analisis yang ada, peneliti akan melakukan penelitian dengan judul "upaya meningkatkan kompetensi berwudhu melalui media lagu pada siswa kelas I SD Negeri Rejodani Ngaglik SlemanTahun Pelajaran 2015/2016".Berdasarkan latar belakang dan identifikasi masalah diatas, maka rumusan masalah dalam penelitian ini adalah sebagai berikut: "Bagaimanakah upaya meningkatkan kompetensi berwudhu melalui media lagu pada siswa kelas I SD Negeri Rejodani Ngaglik SlemanTahun Pelajaran 2015/2016?"Tujuan Penelitian ini adalah untuk mengetahui upaya meningkatkan kompetensi berwudhu melalui media lagu pada siswa kelas ISD Negeri Rejodani Ngaglik SlemanTahun Pelajaran 2015/2016.

Wudhu secara etmologi berasal dari shigat (kata) : wadhua-yaudhu'uwudhuan-wadhoatan, artinya bersih. Menurut Wahbah Al-Zuhali pengertian Al- Wudhuu'u adalah mempergunakan air pada anggota tubuh tertentu dengan maksud untuk membersihkan dan menyucikan. Adapun menurut syara', wudhu adalah membersihkan anggota tubuh tertentu melalui suatu rangkaian aktivitas yang dimulai dengan niat, membasuh wajah, kedua tangan dan kaki serta menyapu kepala.

Berwudhu merupakan salah satu amaliyah ta'abbudiy(pekerjaan ibadah) sebagai syarat sahnya ibadah salat, hal tersebut diperintahkan dalam Al-qur'an surat Al-Maidah ayat 6 yang artinya :

"Hai orang - orang beriman, apabila kamu hendak mengerjakan salat, maka basuhlah mukamu dan tananmu sampai siku dan sapulah kepalamu dan (basuhlah) kakimu sampai kedua mata kaki."

Menurut bahasa, Wudhu artinya Bersih dan Indah. sedangkan menurut istilah (syariah islam) artinya menggunakan air pada anggota badan tertentu dengan cara tertentu yang dimulai dengan niat guna menghilangkan hadast kecil. Wudhu merupakan salah satu syarat sahnya sholat (orang yang akan sholat, diwajibkan berwudhu lebih dulu, tanpa wudhu shalatnya tidak sah.

Menurut Oan Hasanudin (2007 : 29 ) RukunWudhu meliputi ; Niat, Membasuh wajah, Membasuh kedua 
tangan sampai siku, Menyapu kepala, Membasuh kedua kaki sampai mata kaki, Tertib.Arsyad (2010: 3), media berasal dari bahasa latin medius yang secara harfiah berarti 'tengah', 'perantara' atau 'pengantar', yaitu perantara atau pengantar sumber pesan dengan penerima pesan. Dalam bahasa Arab, media adalah perantara atau pengantar pesan dari pengirim kepada penerima pesan.

Gerlach dan Ely (dalam Arsyad, 2010:12-14) mengemukakan tiga ciri media, yaitu (1) ciri fiksatif, ciri ini menggambarkan kemampuan media merekam, menyimpan, melestarikan, dan merekonstruksi suatu peristiwa atau objek; (2) ciri manipulatif, ciri ini memberikan kesan manipulasi terhadap suatu kejadian yang membutuhkan waktu yang lama dalam proses kejadiannya sehingga siswa tetap mampu mengikuti segala proses peristiwa tersebut tanpa mengesampingkan esensi yang ada di dalamnya. Lagu adalah ragam suara yg berirama (dalam bercakap, bernyanyi, membaca, dan sebagainya); nyanyian; ragam nyanyi (KBBI, 2008: 771). Pada penelitian ini media lagu digunakan untuk memudahkan siswa menghafal dan memahami rukun dan sunnah wudhu.

\section{B. Metode Penelitian}

$$
\text { Pelaksanaan }
$$

perbaikan pembelajaran melalui Penelitian Tindakan Kelas dilaksanakan di SD Negeri Rejodani, Sleman. Subjek penelitian adalah kelas I dengan jumlah siswa 33 anak yang terdiri dari 12 siswa laki-laki dan $21 \quad$ siswa perempuan.Waktu pelaksanaan perbaikan pembelajaran melalui Penelitian Tindakan Kelas dimulai dari tanggal 14 Maret 2016 sampai 28 Maret 2016.

Prosedur penelitian yang digunakan dalam penelitian ini adalah penelitian tindakan kelas. Menurut Suharsimi Arikunto (2012: 2-3) Penelitian Tindakan Kelas istilah dalam bahasa Inggris adalah Classroom Action Research (CAR), yaitu sebuah kegiatan penelitian yang dilakukan di kelas. Dikarenakan ada tiga kata yang membentuk pengertian tersebut, maka ada tiga pengertian yang diterangkan.

Terdapat empat tahapan yang lazim dilalui dalam PTK (Suharsimi Arikunto, dkk, 2012: 16), yaitu (1) perencanaan, (2) pelaksanaan, (3)pengamatan, dan (4) refleksi. Adapun model dan penjelasan untuk masing-masing tahap adalah sebagai berikut : 


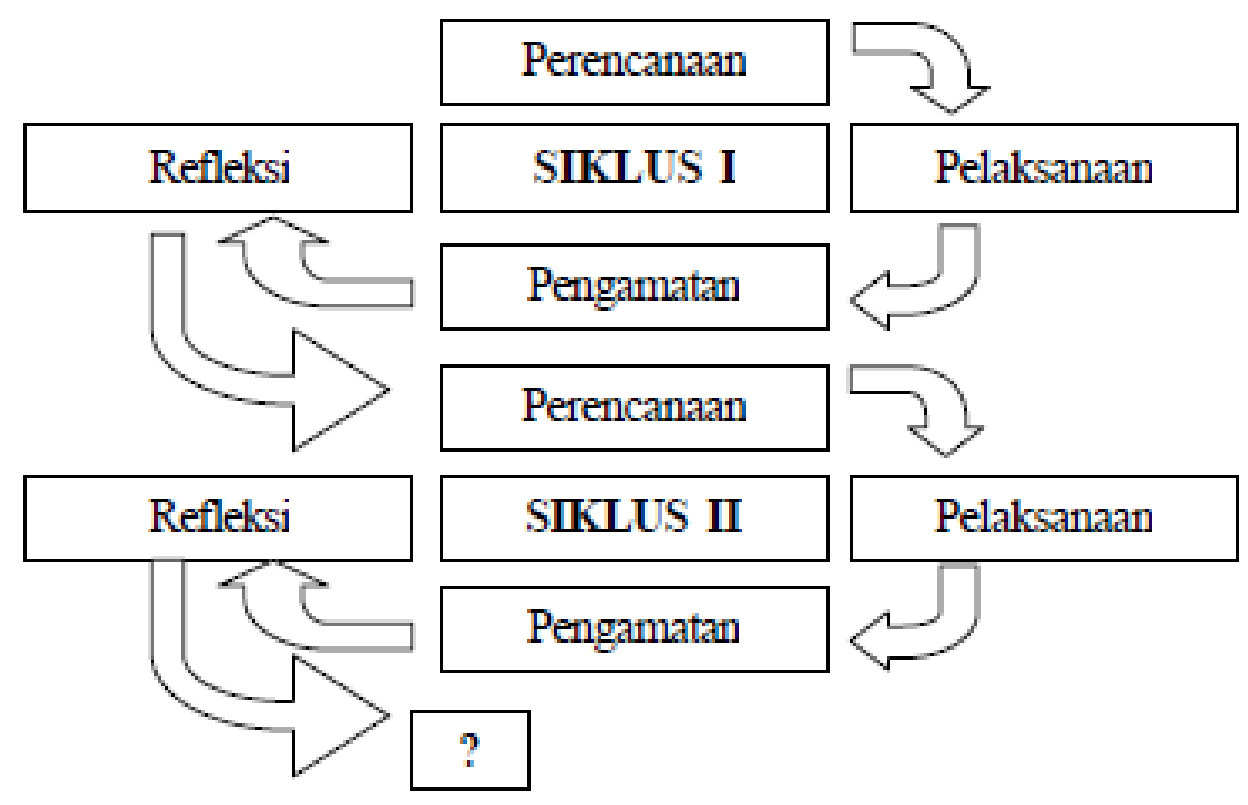

Gambar 1. Prosedur Penelitian Tindakan Kelas

(Suharsimi Arikunto, dkk, 2012: 16)

Teknik analisis data pada

penelitian ini menggunakan analisis deskriptif kualitatif dan analisis deskriptif kuantitatif. Data dari hasil penelitian dianalisis untuk mengetahui kulitas pembelajaran dengan menggunakan media lagu. Analisis deskriptif kualitatif diperoleh melalui pengamatan dengan menggunakan lembar observasi, kemudian dideskripsikan. Sedangkan analisis deskriptif kuantitatif diperoleh melalui menghitung rata-rata pencapaian hasil belajar siswa dengan cara menjumlah seluruh nilai yang diperoleh siswa, kemudian dibagi dengan jumlah siswa.

\section{Hasil Penelitian}

Siklus I

a. Observasi Siswa
Berdasarkan hasil observasi yang dilakukan peneliti, keterlaksanaan kegiatan belajar siswa dengan menggunakan media lagu pertemuan 2 meningkat menjadi $60 \%$ atau kriteria cukup. Pada pertemuan ini siswa kurang membangun pemikirannya untuk berfikir tentang materi yang diajarkan oleh guru, motivasi siswa juga masih rendah.

\section{b. Observasi Guru}

Berdasarkan hasil observasi yang dilaksanakan oleh peneliti, pada pertemuan ini guru sudah melaksanakan pembelajaran menggunakan media lagu, hasil yang didapat sudah meningkat menjadi $70 \%$, hal ini berarti ada peningkatan aktivitas guru dalam melaksanakan 
pembelajaran dengan menggunakan media lagu.

\section{c. Tes Prestasi}

Nilai tes prestasi belajar pada siklus I, mengalami peningkatan. Nilai rata-rata kelas pada siklus I yaitu sebesar 71,67, hal ini mengalami kenaikan dari rata-rata kelas sebelumnya yaitu rata-rata prasiklus 66,06 . Siswa yang tuntas pada siklus I meningkat dari 19 siswa menjadi 25 siswa, sedangkan siswa yang tidak tuntas juga meningkat dari 19 orang berkurang menjadi 8 siswa yang tidak tuntas. Persentase ketuntasan tes prestasi pada siklus I juga mengalami kenaikan dari persentase prasiklus yang besarnya $57,58 \%$ ke siklus I sebesar $75,76 \%$. Sebagian besar siswa sudah mendapat nilai yang bagus, rata-rata sudah mencapai kriteria ketuntasan minimal (KKM) yang ditentukan oleh pihak sekolah yaitu sebesar 70. Peningkatan nilai kompetensi berwudhu siswa pada Siklus II dapat digambarkan dalam gambar 2.

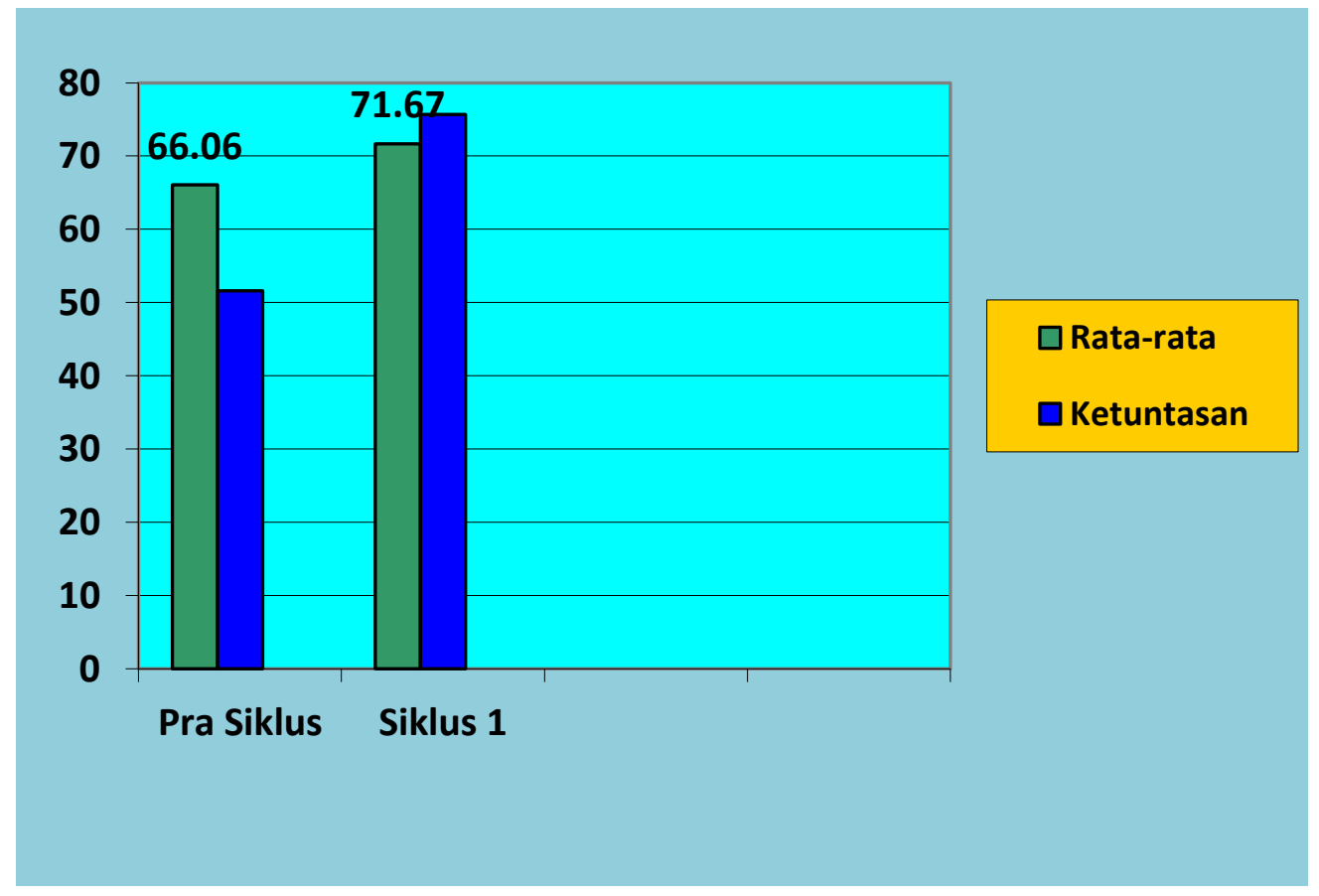

Gambar 2. Grafik Nilai Tes Prestasi Belajar Pra Siklus, Siklus I

Siklus II

\section{a. Observasi Siswa}

Berdasarkan hasil observasi kegiatan siswa yang dilaksanakan oleh peneliti pada Siklus II, aktivitas siswa pada kegiatan pembelajaran mengalami kenaikan secara signifikan dibandingkan dengan siklus I. Pada siklus I, aktivitas siswa yang muncul yaitu 36 dengan persentase $60 \%$. 
Dalam siklus I ini terjadi peningkatan pada pertemuan 1 ke pertemuan 2 sebesar 16,67\%. Pada siklus II, aktivitas siswa yang muncul yaitu 53 dengan persentase sebesar $88,33 \%$.. Hasil persentase $88,33 \%$ yang dalam kategori kriteria aktivitas siswa 75\% < P $100 \%$ termasuk dalam kategori tinggi. Banyak indikator dalam siklus II yang mengalami kenaikan. Hal ini menunjukkan bahwa kegiatan observasi kegiatan siswa mengalami keberhasilan.

\section{b. Observasi Guru}

Berdasarkan hasil observasi
yang dilaksanakan oleh peneliti,
aktivitas pembelajaran guru dalam
kegiatan pembelajaran mengalami
peningkatan yang baik. Dalam siklus I
aktivitas guru yang muncul sebanyak
14 indikator dengan persentase $70 \%$.
Pada Siklus II 95\% atau 19 aktivitas
guru sudah muncul dan hanya 1
aktivitas guru yang tidak muncul dan
mengalami peningkatan 15\%. Hasil
$95 \%$ ini memenuhi kriteria tabel $75 \%$
$<\mathrm{P}=100 \%$ adalah tinggi.

\section{c. Tes Prestasi}

Nilai Tes Prestasi pada Siklus II sangat baik dan mengalami kenaikan dibandingkan dengan siklus I. Perhatian siswa akan kegiatan pembelajaran pada siklus II ini tinggi. Siswa sangat tertarik dengan kegiatan pembelajaran dengan media lagu. Banyak siswa yang antusias dalam mengikuti proses pembelajaran. Ratarata nilai siswa berdasarkan hasil penelitian yang telah dilakukan pada Siklus 1 yaitu sebesar 71,67 dengan persentase ketuntasan sebesar 75,76\%. Siswa yang tuntas sebanyak 25 siswa dan yang tidak tuntas sebanyak 8 siswa. Pada Siklus II, rata-rata kelas mencapai 82,12 dengan persentase ketuntasan sebesar $87,88 \%$. Siswa yang tuntas sebanyak 29 siswa dan yang tidak tuntas sebanyak 4 siswa.

\section{Peningkatan nilai kompetensi} berwudhu siswa pada Siklus II dapat digambarkan dalam histogram di bawah ini. 


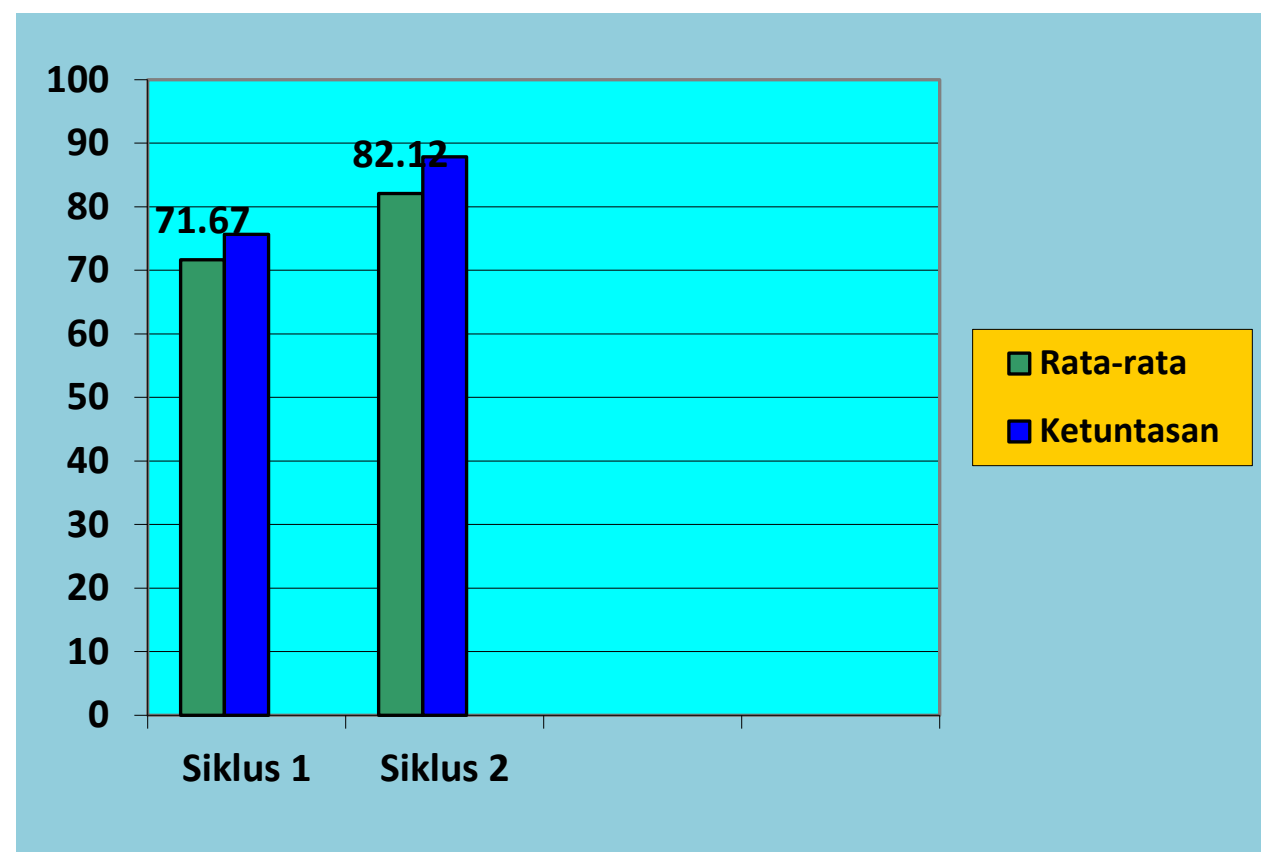

Gambar 3 Grafik Nilai Tes Prestasi SiklusI, II

\section{Pembahasan}

Apabila dilihat dari keberhasilan, dapat diketahui bahwa sebelum diadakan penelitian tindakan kelas ini, pada umumnya minat siswa terhadap pembelajaran praktek ibadah sangat kurang dan kompetensi berwudhu rendah, hal tersebut dapat dibuktikan dari identifikasi awal melalui wawancara. Lain halnya setelah diadakannya penelitian tindakan kelas yang menerapkan media lagu sebagai metode pembelajaran berwudhu minat siswa terhadap pembelajaran PAI umumnya dan pembelajaran berwudhu pada khususnya sangat antusisias hal tersebut menunjukkan bahwa media lagu ternyata dapat meningkatkan minat siswa terhadap pembelajaran berwudhu bagi siswa Sekolah Dasar.

Kualitas proses belajar siswa setelah media lagu diterapkan meningkat, hal tersebut menunjukkan bahwa media lagu dapat meningkatkan kompetensi menghafalurut-urutan berwudhu dan menciptakan pembelajaran yang menarik dan menyenangkan, sebagaimana hasil nilai tes formatif dalam table 7 . 


\begin{tabular}{|c|c|c|c|}
\hline & $\begin{array}{c}\text { Pra } \\
\text { Siklus }\end{array}$ & $\begin{array}{c}\text { Siklus } \\
\end{array}$ & $\begin{array}{c}\text { Siklus } \\
\end{array}$ \\
\hline Rata-rata & 66,06 & 71,67 & 82,12 \\
\hline Ketuntasan & $57,58 \%$ & $75,76 \%$ & $87,88 \%$ \\
\hline
\end{tabular}

Tabel 1. Rekapitulasi Nilai Tes Prestai Belajar Prasiklus, Siklus I, dan Siklus II

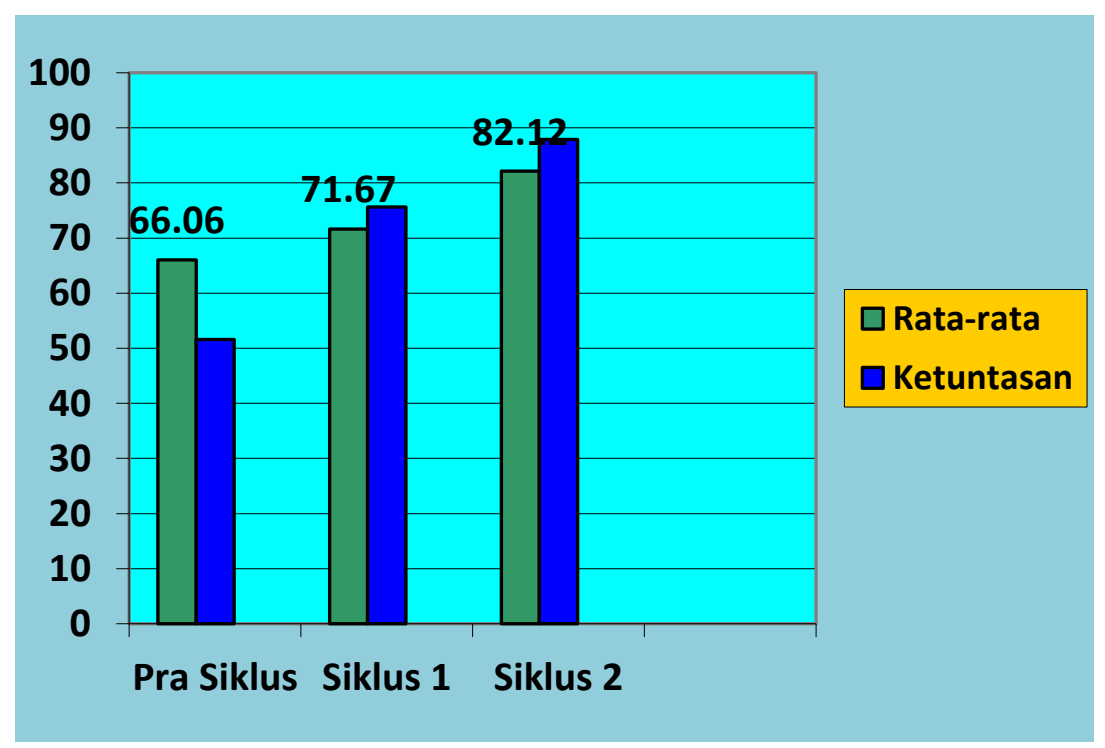

Gambar 4. Grafik Perbandingan Nilai Prasiklus, Siklus I, dan Siklus II

Melalui media lagu hasil pembelajaran kompetensi berwudhu meningkat hal tersebut dapat dibuktikan berdasarkan data observasi dari penilaian proses dan hasil ujuk kerja yang menunjukkan nilai yang signifikan dari pra tindakan atau tes awal nilai ratarata siswa kelas II 66,06 kemudian setelah dikenai tindakan melalui media lagu meningkat menjadi 82,12.

Apabila dikembalikan pada hipotesis penelitian, menunjukkan apabila pembelajaran berwudhu pada siswa SD kelas I menggunakan media lagu, maka, kompetensi siswa dalam praktek beribadah khususnya berwudhu meningkat, serta kompetensi menghafal urut-urutan berwudhu juga meningkat.

\section{E. Simpulan}

Berdasarkan hasil penelitian dan pembahasan maka dapat diambil kesimpulan bahwa penerapan pembelajaran melalui media lagudapat meningkatkan kompetensi berwudhu pada siswa kelas I SD Negeri Rejodani Ngaglik SlemanTahun Pelajaran 
2015/2016. Hal ini dapat dibuktikan melalui hasil penelitian sebagai berikut:Persentase ketuntasan belajar siswa mengalami peningkatan tiap siklusnya. Pada saat prasiklus rata-rata prestasi belajar 66,06 dengan ketuntasan $57,58 \%$, siklus I rata-rata prestasi belajar 71,67 dengan ketuntasan 75,76\%, dan siklus II rata-rata prestasi belajar 82,12 dengan ketuntasan $87,88 \%$. Adanya peningkatan aktivitas siswa dan aktivitas guru dalam pembelajaran PAI. Aktivitas siswa pada siklus I sebesar $60 \%$. Pada siklus II meningkat menjadi $88,33 \%$. Sedangkan aktivitas guru siklus I sebesar 70\%. Pada siklus IImeningkat menjadi $95 \%$.

\section{DAFTAR PUSTAKA}

Arsyad, Azhar. 2002. Media Pembelajaran. Jakarta: PT. Raja Grafindo.

Oan Hasanudin, 2007, Mukjizat Berwudhu. Jakarta : Qultum Media

Suharsimi Arikunto. 2009. Penelitian Tindakan Kelas. Jakarta: Bumi Aksara

Suharsimi Arikunto, Suhardjono, dan Supardi. 2012. Penelitian Tindakan Kelas. Jakarta: Bumi Aksara 